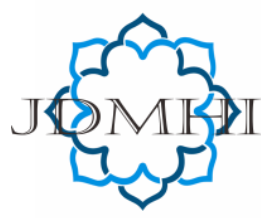

email: jdmhi@walisongo.ac.id

Journal of Digital Marketing and Halal Industry

ISSN: 2716-4810 (print) ISSN: 2716-4802 (online)

\title{
Green Marketing Exploration on Customer Retention in Improving Business Performance with Tacit Entrepreneurship Knowledge as Moderator
}

\section{Fadjar Setiyo Anggraeni}

Universitas AKI Semarang, Indonesia

\section{A R T I C L E I N F O}

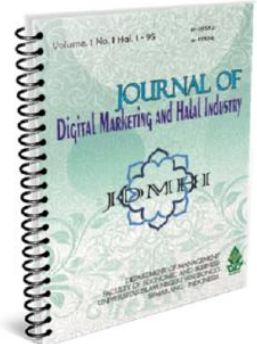

Article history:

Received 21 Mey 2020

Accepted 18 October 2020

Published 30 October 2020

Keywords:

green marketing, customer retention, tacit entrepreneurial knowledge
A B S T R A C T

Global warming is a central issue, so it needs strategic steps for organizations or companies to find solutions because it threatens the future. This article aims to provide an overview of the importance of research on the role of green marketing and customer retention in improving business performance, using the factor of tacit entrepreneurial knowledge as a moderating variable. This research is qualitative, using a library research approach. The results obtained six preparations: First, the more effective the implementation of green marketing by the organization, the more it will improve customer retention patterns. The second proposition, the more effective green marketing is, the more business performance will be-the third proposition, the stronger the customer retention, the stronger the effect on improving organizational performance. The fourth proposition, the higher tacit knowledge about entrepreneurship possessed by organizations and individuals followed up intensively through interaction with customers, the customer resistance will increase, and the higher tacit knowledge owned by organizations and individuals in it, the more effective it will be. Green marketing. The fifth proposition, the higher the organization's tacit knowledge and the individuals in it, the higher the organizational performance will be.

@2020 Journal of Digital Marketing and Halal Industry

\section{Introduction}

An increase in global temperature is now suspected of causing other changes such as rising sea levels, increasing intensity of extreme weather phenomena, and changes in the amount and precipitation pattern. Global

\footnotetext{
* Corresponding author.email:fadjar@unaki.ac.id DOI: http://dx.doi.org/10.21580/jdmhi.2020.2.2.6351
} 
warming is also affecting agricultural yields, the loss of glaciers, and the extinction of various species of animals. Until now, politics and the public worldwide are still debating what, if any, action should be taken to reduce or even reverse global warming or adapt to other consequences that will arise later.

Global warming has become a universal central issue. It has become the concern of some audiences regarding how an organization or company can find solutions to problems that threaten the future. The world has made many efforts to conduct socialization that promotes life sustainability on earth. Many green campaigns are carried out to eliminate or at least reduce business practices resulting in pollution and disrupt living ecosystems. Demands to reduce fossil energy use such as petroleum, which is one of the global warming causes, and other challenges have been raised.

Global warming and garbage are threats to the world, including Indonesia. B Corp Community Indonesia, community companies and organizations, even appealed to business people to find solutions to minimize this threat. They demand that these entrepreneurs carry out balanced business practices, namely not only focusing on generating profits but also positively impacting the environment and society. This awareness and concern for the environment and health have changed the perspective, community lifestyle, and business actors. The business pattern approaches taken begun to lead to environmental sustainability based on the business activity approach. Green marketing is here to provide answers to demands from various activists who care about the environment. Green marketing steps many producers have responded positively to. Many research results on green marketing also reinforce the importance of green marketing in business.

The findings of research from Daniel $F$. Spulber (2012) are as follows. First, Spulber demonstrates tacit knowledge, which implies that high-quality inventions lead to entrepreneurship, whereas low-quality innovations result in technology transfer. Second, Spulber pointed out that while investment in $R \& D$ and absorptive capacity complements technology transfer, they can be strategic substitutes in the innovation game with entrepreneurial options. Third, Spulber shows that introducing innovative entrepreneurial opportunities can increase R\&D investment and decrease absorption investment. Finally, Spulber finds that the equilibrium probability of entrepreneurship decreases in $R \& D$ costs, increases in technology transfer costs, and falls in startups' set-up costs. This article aims to provide an overview of the importance of research on the role of green marketing and customer retention in improving business performance, using the factor of tacit entrepreneurial knowledge as a moderating variable.

\section{The Method, Data, and Analysis}

This study uses a qualitative approach using a literature study. Data used are library sources, books, research results, internet sources, and other relevant data. The data analysis technique used a descriptive analysis approach.

\section{Result and Discussion}

\section{Entrepreneurship}


The independent translation of entrepreneurship is what a person can independently handle their career and dreams and direct them towards their own choice, without any orders and controls from others or restrictions such as schedules, ideas, etc. Entrepreneurs can take the first steps towards making the world a better place for everyone in it. The term entrepreneur, which most people know as one who organizes and assumes the business risk in exchange for profit, seems to have been introduced by Richard Cantillon (1697-1734), an Irish economist of French descent. The term came into wide use after John Stuart Mill popularized it in his 1848 classic, Principles of Political Economy. Still, it all disappeared from economic literature in the late nineteenth century. Entrepreneurship has different meanings among experts or sources of reference because of other points of emphasis and emphasis. Entrepreneurship includes the activities required to create or carry out a company when all the markets have not been or have not been identified, or the components of the production function are not fully known (Harvey Leibenstein, 1968, 1979).

Over the last decade, research in small company entrepreneurship has documented various issues regarding the importance of environmental factors. These problems include the capabilities and resources type, also management practices, concerning the company's operations, and supply chain systems, branding and marketing strategies (Chen, 2010; Kumar et al.,2015; Duffett et al., 2018; Khan, 2017), investment and financing (Nakamura, 2011; Bose 2012; Khan, 2020) and matters related to services (Tzschentke et al., 2008; Aykol et al., 2015). Thus it can be said that there has been a paradigm shift in business and company management. The business concept that the company runs must be followed by corporate social and environmental responsibility, including paying attention to the social and ecological impacts.

From the description above, it can be understood that entrepreneurship and all its problems require serious handling from business actors if they still want their business to be sustainable. The strategy he takes must be a long-term strategy that considers the element of short-term profit and the sustainability of the environment around the place of business, which will impact the sustainability of his business distribution chain. Besides that, the significant effect is loyal customers as a form of other benefits he receives.

\section{Green Marketing}

According to the small Business Chron, green marketing is a marketing process that refers to the environment. Where this must-have marketing benefits for the environment or nature. In other words, this is marketing that doesn't harm wildlife and the environment. Green marketing has an essential role in enhancing the image, especially the perception of Green Brand because the green advertisement is specifically for brands that have the goal of caring for the environment, and so will create purchasing decisions (Ristanti, no year). Ristanti's study results show that green marketing has a direct and significant effect on buying interest. Green marketing has no direct and significant effect on purchasing decisions. Sedengkan buying interest has a direct and significant effect on purchasing decisions. Green marketing has an indirect and significant effect on 
purchasing decisions, with buying interest as an intervention variable.

Few studies on the factors influence purchase intention, especially for environmentally friendly products and customer loyalty. As a result, current research seeks to identify intrinsic (green product quality and green trust) and extrinsic (age, education, and employment status) factors that influence customer attitudes (as moderating factors) and loyalty to the consumption of environmentally friendly products (Baktash and Talib, 2019). The study found that there was a significant effect of quality and trust on customer attitudes and loyalty. Also, age and education significantly impact customer attitudes towards environmentally friendly product quality. Meanwhile, a study on proenvironmental customer behaviour conducted by Chung (2019) also states that this behaviour provides economic benefits for the community and ensures sustainable environmental development. The economy and green strategy are essential in today's hotel system. This study found that hotel corporate social responsibility stakeholders and executives can indirectly increase consumer loyalty to hotel image through environmentally friendly marketing.

Research in the previous year conducted by Lin et al. (2017) also showed that providing practical and self-expressive benefits directly enhances the image from the brand's green. Also, valuable services and image brand's green have a direct influence on loyalty brand's green. The perceived risk of a brand's green negatively moderates the relationship between practical benefits and the green image brand. The study conducted by Mele et al. (2019) is useful to show that outside of the direct influence of green marketing on the indicator, green word of mouth has other indirect effects represented by other mediating variables, namely green attitudinal loyalty and green trust. From this study, green marketing measures significantly affect their indirect relationship with word of mouth than on their direct connection. That loyalty is an aspect with the most substantial influence regarding trust.

The various studies conducted above provide new insights for Green Marketing, representing its concern for environmental sustainability. Green marketing becomes a solution and a bridge for multiple interests in the cycle of a product from where the raw materials are obtained until it is distributed to end-users' hands, namely customers.

Proposition 1: The more effective the organization's implementation of gene marketing, the more it will improve customer retention patterns.

Findings from Hasan and Ali (2015) lead to conclusions about the relationship between green innovation and green promotion with company performance. They agree that green innovation performance and green advertising have a positive effect on company performance. Meanwhile, the empirical results of a study conducted by Han Lin et al. (2019) show that companies with higher environmental ethics are more likely to implement green marketing programs consisting of green production, price, distribution, and promotion programs and then improve company performance.

Today's eco-friendly approach is a must for the business world from various aspects of its activities. Green marketing strategy is one of 
the green policies, especially in the manufacturing industry, affecting environmental results and company performance. In line with the previous studies' works, the findings of Goh, W. H et al. (2019) show that green products, green price, and green promotion have a significant effect on company performance.

Proposition 2: The more effective green marketing is, the more business performance will be.

\section{Customer Retention}

In marketing, people tend to use the words customer then consumer almost interchangeably. However, customers and consumers are not the same. Customers and consumers both use products from one manufacturer. However, customers will buy the same product made and marketed by a company, over and over. This can happen when the company can carry out the strategy well, and consumers will feel satisfied and comfortable with the products and services that the company sells to consumers. When it goes well, there is a possibility that consumers will buy again and can recommend products from the company. (Lompoliuw et.al, 2019).

A study from Ascarza et al. (2018) presents an integrated framework for managing retention that takes advantage of emerging opportunities offered by new data sources and new methodologies such as machine learning (see figure 1). A unified framework for retention management. The framework takes a holistic view of customer retention, starting with a data and method foundation, and continuing with single campaign design and management, cross-campaign coordination, and integration with marketing strategies. Central to the framework is the development of individual retention campaigns. They expand on current practices in several ways, for example, recognizing that the customers with the highest risk of not being retained do not have to overlap $100 \%$ with those who should be targeted.

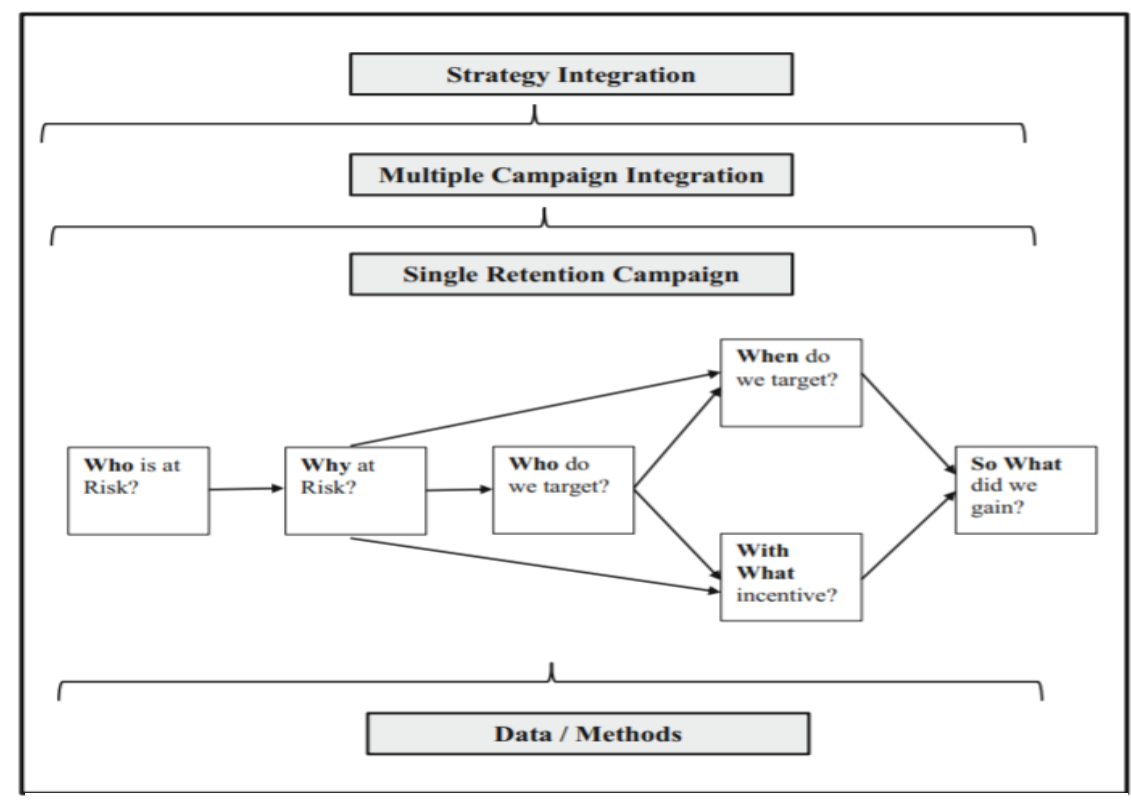

Figure 1. Customer Retention On Management Framework 
Figure 1 shows the framework initiated by Ascarza et al. (2018). Starting with maintaining infrastructure, data, and methods, gradually designing one campaign, coordinating multiple drives, and incorporating retention with a marketing strategy. The main difference is between passive activity and active activity. In the passive activity, the company waits for customers to mingle and then return the customer through financial incentives. Inactive training, the company takes steps first to resolve the problem that caused the shuffle. Both methods face their respective challenges. The recommended client processing steps are: First, identify clients who may be withheld. Second, a diagnosis of why each customer is at risk. Third, determine the customers who are the target of the campaign. Next, decide when to target these customers and what incentives and actions to take. Lastly, launch a campaign and evaluation

While the study results by Ciunova et al. (2017) show that SMEs can improve their customer loyalty performance by developing their orientation to create customer retention and brand value while at the same time maintaining brand consistency. These results confirm only a positive relationship between brand orientation and financial performance, partly mediated by customer loyalty. Meanwhile, according to McCrory et al. (2017) to achieve customer retention, with senior management support, a comprehensive corporate approach is essential, requiring open communication, employee empowerment, and recruiting the "right" people. Through specific organizational investments and ongoing customer research, the framework is viable.
Based on previous studies, customer retention is essential because a company's life will depend on customer loyalty to our products and the brand image. So this paper proposes the following:

Proposition 3: The more robust the customer retention, the stronger the effect on improving organizational performance.

\section{Tacit knowledge}

Knowledge, as explained by Koenig (2012), can be categorized as explicit (formally recorded) or implicit (known but not recorded officially). Nonaka, Toyama et al. (2000) argue that organizations create and manage knowledge in a very dynamic way. Spulber (2012) states that tacit knowledge makes a fundamental trade-off between inventors' use of their inventions and others' adoption of innovations. To address this trade-off, Spulber presents a formal model that examines how knowledge tacit and inventors can influence the choice between innovative entrepreneurship and technology transfer. Creative entrepreneurial intentions transform the market for discovery and influence inventors 'investment in research and development $(R \& D)$ and potential adopters' investment in discovery absorption.

According to Al Hashem (2020), tacit knowledge is knowledge or a human way of thinking that is difficult to express and articulate, in the form of intuition, experience, insight, and hunch. Therefore, tacit knowledge can be changed by using faceto-face communication or using information technology. The results of the research by Pereira et al. (2012) that tacit employee knowledge as a result of interaction can enable companies to obtain and maintain 
customer satisfaction during subsequent visits and uses. In this case, customer retention has been created.

Based on several studies described above, propositions related to the relationship between tacit knowledge and customer resistance are presented in this paper, namely:

Proposition 4a: The higher tacit knowledge about entrepreneurship possessed by organizations and individuals is followed up intensively through interactions with customers, then will increase customer resistance

In the previous discussion on green marketing, propositions 1 and 2 stated that green marketing is an environmentally sound marketing process that still refers to natural preservation. Green Marketing is also a company effort to convince users of its products that they concern about nature preservation. However, green marketing will not run effectively if it is not supported by knowledge from entrepreneurs or human resources within the organization. This knowledge can be obtained through the learning process, and it can also be obtained through tacit knowledge from employers or employees. Meanwhile, to exploit the relationship between practical experience and prescriptive knowledge, Selden (2019) argues that the first thing that needs to be addressed is the problem that most "knowledge" signatures implicit at the time of forwardlooking real-time practice. In other words, practitioners were not immediately aware of"knowledge" tacit their. Research has not been found related to the influence of tacit knowledge on efforts green marketing, so this paper will be discussed as a novelty and raises the following proposition:

Proposition 4b: The higher the tacit knowledge possessed by organizations and individuals, the more increased effectiveness of green marketing.

Therefore, knowledge, tacit, which is often encountered in entrepreneurial practice but rarely felt or understood by the owner, can be developed through entrepreneurs' knowledge management to other prospective entrepreneurs, including tacit regarding the importance of environmental sustainability at work. The research results show the importance of knowledge management by Muthuveloo et al. (2017), which confirms the importance of knowledge creation and management, especially those with tacit knowledge, for academics and practitioners. This is especially important for those who come from the top management of any organization, who strive to prosper and improve their organization's performance for better operation of business functions and returns on investment. According to Ping Huang (2017), company performance is closely related to individual ability to take advantage of social networks, and collective knowledge to understand the business environment, and practical skills in dealing with potential risks. The study also discussed the impact of expertise tacit on innovation. Tacit knowledge has negative and positive effects on design, stemming from innovation's transferability across individuals and companies.

Tacit knowledge is closely related to the ability to take advantage of networking and understanding the business environment individually and collectively. Tacit knowledge is essential for top management in knowledge creation and management to increase welfare and organizational performance. The final proposition expressed in this paper is related 
to the relationship between tacit knowledge and organizational performance, namely:

Proposition 5: The higher the organization's tacit knowledge and the individuals in it, the more organizational performance.

Figure 2: Research Conceptual Model

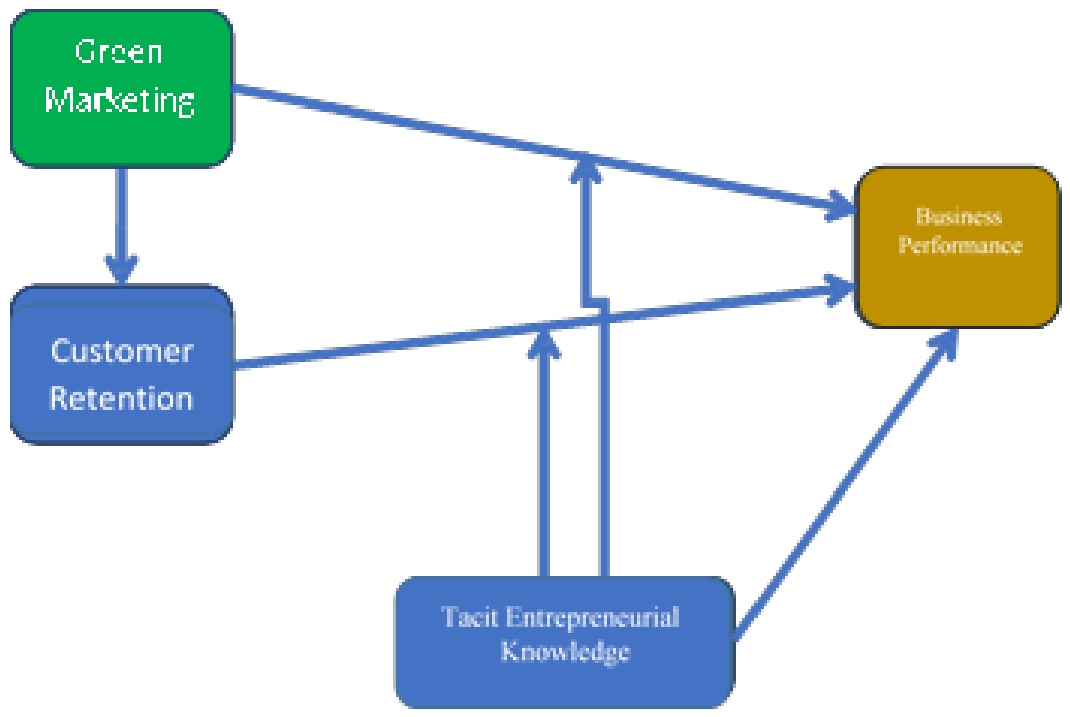

\section{Conclusion}

This research is proposed to be carried out because of green marketing research scarcity, especially in Indonesia. Moreover, medium, small, and micro-entrepreneurs still have to calculate the costs incurred due to implementing green management. This is a challenge to find solutions to MSME problems in Indonesia. The framework in Figure 2 above highlights some interesting issues for future research. The framework shows a direct relationship between green marketing and business performance and customer retention and business performance. However, Peru can also see that, directly, it can be found that green marketing also affects customer retention rates. Entrepreneurial tacit knowledge is proposed to reinforce the green marketing role and customer retention in improving business performance, although tacit knowledge can directly impact business performance. Future researchers can use the conceptual research framework above.

\section{References}

Al-Hashem, A. O. (2020). IT-based Knowledge Management Processes, E-Services Innovation and E-loyalty. Journal of Theoretical and Applied Information Technology, 98(10). Aykol, B.; Leonidou, L.C. Researching the green practices of 
smaller service firms: A theoretical, methodological, and empirical assessment. J. Small Bus. Manag. 2015, 53, 12641288. [CrossRef]

Ascarza, E., Neslin, S. A., Netzer, O., Anderson, Z., Fader, P. S., Gupta, S., ... $\&$ Provost, F. (2018). In pursuit of enhanced customer retention management: Review, key issues, and future directions. Customer Needs and Solutions, 5(1-2), 65-81.

Baktash, Leila. Talib, Muzalwana Abdul (2019). Green marketing strategies: exploring intrinsic and Extrinsic Factors towards Green Customers' Loyalty. QUALITY Access to Success Vol. 20, No. 168/ February 2019

Bose, I.; Pal, R. Do green supply chain management initiatives impact stock prices of firms? Decis. Support Syst. 2012, 52, 624-634. [CrossRef]

Chen, Y.-S. The drivers of green brand equity: Green brand image, green satisfaction, and green trust. J. Bus. Ethics 2010, 93, 307319. [CrossRef]

Dalkir, K. (2017). Knowledge management in theory and practice. MIT press.

Devi Eprilia Ristanti. (tanpa tahun). Pengaruh Produk Yang Berwawasan Hijau Terhadap Minat Beli Produk Air Minum Dalam Kemasan Merek Ades

Chung, K. C. (2019). Green marketing orientation: Achieving sustainable development in green hotel management. Journal of Hospitality Marketing \& Management, 1-17.

Ciunova-Shuleska, A., PalamidovskaSterjadovska, N., Osakwe, C. N., \& Omotoso, J. (2017). The impact of customer retention orientation and brand orientation on customer loyalty and financial performance in SMEs: Empirical evidence from a Balkan country. JEEMS Journal of East European Management Studies, 22(1), 83-104.

Du_ett, R.; Edu, T.; Haydam, N.; Negricea, I.C.; Zaharia, R. A Multi-Dimensional Approach of Green Marketing Competitive Advantage: A Perspective of Small Medium and Micro Enterprises fromWestern Cape, South Africa. Sustainability 2018, 10, 3764. [CrossRef]

Goh, W. H., Goh, Y. N., Ariffin, S. K., \& Salamzadeh, Y. (2019). How green marketing mix strategies affects the firm's performance: a Malaysian perspective. International Journal of Sustainable Strategic Management, 7(12), 113-130.

Han, M., Lin, H., Wang, J., Wang, Y., \& Jiang, W. (2019). Turning corporate environmental ethics into firm performance: The role of green marketing programs. Business Strategy and the Environment, 28(6), 929-938.

Hislop, D., Bosua, R., \& Helms, R. (2018). Knowledge management in organizations: A critical introduction. Oxford university press.Huang, K. P. (2017). Entrepreneurial education: The effect of entrepreneurial political skill on social network, tacit knowledge, and innovation capability. Eurasia Journal of Mathematics, Science and Technology Education, 13(8), 5061-5072.

Jiang, Z., Wang, Z., \& Feng, C. (2020). Balancing the strength of external and internal tie for tacit knowledge management. Technology Analysis \& Strategic Management, 1-16. 
Khan, E.A. An investigation of marketing capabilities of informal microenterprises: A study of street food vending in Thailand. Int. J. Sociol. Soc. Policy 2017, 37, 186-202. [CrossRef] Sustainability 2020, 12, 221 15 of 17

Khan, E.A.; Quaddus, M.; Weber, P.; Geneste, L. Micro-Start-Ups financial capital and socio-economic performance: In a poor financial resource setting. J. Dev. Areas 2020, 54, 95-107. [CrossRef]

Koenig, M. E. (2012). What is KM? Knowledge management explained. KMWorld. Inf. Today, Inc, 4.

Kumar, P. Green marketing innovations in small Indian firms. World J. Entrep. Manag. Sustain. Dev. 2015, 11,176-190. [CrossRef]

Lin, J., Lobo, A. and Leckie, C. (2017), Green brand benefits and their influence on brand loyalty, Marketing Intelligence \& Planning, Vol. 35 No. 3, pp. 425440. https://doi.org/10.1108/MIP-09. 2016-0174

Lompoliuw, T. S., Pio, R. J., \& Runtuwene, R. F. (2019). Faktor-Faktor Yang Mempengaruhi Customer Retention Di PT. Erafone Mega Mall Manado. JURNAL ADMINISTRASI BISNIS (JAB), 9(1), 114-121.

McCrory, B., Pilcher, N., \& McMillan, J. (2017). A holistic framework to embed good company practice for customer retention. The TQM Journal, 29(2), 257275. doi:10.1108/tqm-11-2015-0139

Muthuveloo, R., Shanmugam, N., \& Teoh, A. P. (2017). The impact of tacit knowledge management on organizational performance: Evidence from Malaysia. Asia Pacific
Management Review, 22(4), 192-201.

Nakamura, E. Does environmental investment really contribute to firm performance? An empirical analysis using Japanese firms. Eurasian Bus. Rev. 2011, 1, 91-111.

Pereira, C. A. B., Ferreira, J. J. M., \& Alves, H. M. B. (2012). Tacit Knowledge as Competitive Advantage in Relationship Marketing: A Literature Review and Theoretical Implications. Journal of Relationship Marketing, 11(3), 172197. doi:10.1080/15332667.2012.70524 9

Pérez-Luño, A., Alegre, J., \& Valle-Cabrera, R. (2019). The role of tacit knowledge in connecting knowledge exchange and combination with innovation. Technology Analysis \& Strategic Management, 31(2), 186-198.

Raudeliūnienè, J., \& Davidavi ien, V. (2018). Knowledge management process model. Entrepreneurship and Sustainability Issues, 5(3), 542-554.

Razzaq, S., Shujahat, M., Hussain, S., Nawaz, F., Wang, M., Ali, M. and Tehseen, S. (2019), Knowledge management, organizational commitment and knowledgeworker performance: The neglected role of knowledge management in the public sector, Business Process Management Journal, Vol. 25 No. 5, pp. 923. 947. https://doi.org/10.1108/BPMJ-032018-0079

Selden, P. D., \& Fletcher, D. E. (2019). The tacit knowledge of entrepreneurial design: Interrelating theory, practice and prescription in entrepreneurship research. Journal of Business Venturing Insights, 11, e00122.

Spulber, Daniel F. (2012). Tacit knowledge with 
innovative entrepreneurship. International Journal of Industrial Organization Volume 30, Issue 6, November 2012, Pages 641-653 https://doi.org/10.1016/j.ijindorg.2012. 07.004

Tzschentke, N.; Kirk, D.; Lynch, P. Ahead of their time? Barriers to action in green tourism firms. Serv. Ind. J. 2008, 28, 167-178. [CrossRef] 
Journal of Digital Marketing And Halal Industry

Vol. 2, No. 2 (2020) 121-132 